\title{
Suprasellar germ cell tumor in a dog
}

\author{
Tumor supra-selar de células germinativas em um cão
}

\author{
Raquel Rubia Rech ${ }^{\mathrm{I}}$ Soraia Figueiredo de Souza ${ }^{\mathrm{I}}$ Marcia Cristina da Silva ${ }^{\mathrm{I}}$ \\ Alexandre MazzantiII Derron Anthony Alves ${ }^{\mathrm{III}}$ Claudio Severo Lombardo de Barros ${ }^{\mathrm{IV}}$
}

- NOTE -

\begin{abstract}
A case of suprasellar germ cell tumor is described in a 6-year -old Airedale Terrier bitch that presented behavioral changes and abrupt onset of blindness. The neoplasm compressed the ventral surface of the cerebrum from the level of basal ganglia to the mesencephalon. Histologically the neoplasm consisted of nests and trabeculae of round to polygonal cells that occasionally surround tubules and cysts formed by columnar cells. Neoplastic cells are immunopositive for cytokeratin and alpha-fetoprotein. The diagnosis was based on location, histological appearance and on the immunohistochemical staining.
\end{abstract}

Key words: extragonadal germ cell tumor, canine neoplasms, central nervous system.

\section{RESUMO}

É descrito um caso de tumor de células germinativas supra-selar em numa cadela Airedale Terrier de seis anos de idade, que apresentou transtornos do comportamento e aparecimento abrupto de cegueira. $O$ neoplasma comprimia a superfície ventral do cérebro desde a altura dos núcleos basais até o mesencéfalo. Histologicamente, o neoplasma consistia de ninhos e trabéculas de células redondas ou poligonais que ocasionalmente arranjavam-se ao redor de túbulos e cistos formados por células colunares. As células neoplásicas foram positivas na imunoistoquímica para citoqueratina e $\alpha$-fetoproteína. O diagnóstico foi feito com base na localização do tumor, no seu aspecto histológico e nos resultados da marcação imunoistoquímica.
Palavras-chave: tumor de células germinativas extragonadal, neoplasmas de cães, sistema nervoso central.

Extragonadal germ cell tumors can originate from the transformation of the otherwise normal resident population of germ cells, of a developmentally derived ectopic rest of germ cells, or of germ cells that migrated into the central nervous system late in development (FERREIRA et al., 2003; NYSKA et al., 1993). Usually, germ cells migrate from the wall of the yolk sac to the primitive gonad. As a rule, these germ cells do not survive and are eliminated by immune mechanisms; those cells which do survive may undergo neoplastic transformation (FERREIRA et al., 2003). Most extragonadal germ cell tumors in humans arise intracranially in midline diencephalic structures, i.e., the pineal region or the suprasellar-hypothalamohypophyseal axis (PATTERSON-KANE et al., 2001). In dogs, the majority of germ cell tumors occur in the ovaries and testicles; few extragonadal neoplasms are reported in the intracranial suprasellar region (HARE et al., 1993; SUMMERS et al., 1995; VALLENTINE et al., 1988) and there is one report of mixed germ cell tumor in the spinal cord (FERREIRA et al., 2003) and

'Programa de Pós-graduação em Medicina Veterinária (PPGMV), Centro de Ciências Rurais (CCR), Universidade Federal de Santa Maria (UFSM), Santa Maria, RS, Brasil.

ILLaboratório de Cirurgia Experimental, Departamento de Cirurgia, CCR, UFSM, Santa Maria, RS, Brasil.

III Armed Forces Institute of Pathology, Washington D.C., USA.

${ }^{\text {IV }}$ Departamento de Patologia, UFSM, 97105-900, Santa Maria, RS, Brasil. Email: claudioslbarros@uol.com.br. Autor para correspondência. 
another one in the eye (PATTERSON-KANE et al., 2001).

A 6-year-old, Airedale Terrier bitch was presented with a history of behavioral changes and abrupt onset of blindness of 7 days duration. Clinical examination revelead apathy, ventromedial unilateral strabismus of the left eye and stiffness of the neck. There was $64 \mu \mathrm{g} / \mathrm{dl}$ protein in the cerebrospinal fluid. Hematology and blood chemistry profiles were within the normal range. In spite of therapy with corticosteroids and antibiotics, the clinical condition deteriorate and the dog died three days after admission. Gross pathology consisted of 5 x 4 x 4cm suprasellar mass which compressed the ventral surface cerebrum from the level of basal ganglia to the mesencephalon (Figura 1A). The cut surface of the mass was soft, red alternated with white areas. The pituitary gland could not be found. No other gross lesions were seen at necropsy.

Tissues were fixed in $10 \%$ formalin, embedded in paraffin, sectioned at $5 \mu \mathrm{m}$, and stained with hematoxylin and eosin (HE). Immunohistochemical staining for alpha-fetoprotein (AFP) and cytokeratin were performed in selected slides. Positive controls were fetal liver (for AFP) and skin (for cytokeratin).

Microscopically, compressing and invading the cerebral parenchyma, there was an unencapsulated, expansile neoplasm composed of nests and trabeculae of round to polygonal cells that occasionally surrounded tubules and cysts formed by columnar cells (Figura 1B). All were supported on a fine fibrovascular stroma. The first population had variable distinct borders and moderate amounts of eosinophilic cytoplasm that frequently contained discrete clear vacuoles in a subpopulation somewhat resembling hepatocytes. Rarely, cells contained multiple,

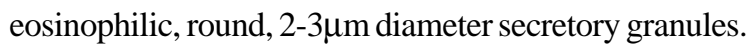
Occasionally, columnar cells lining cystic spaces had cilia. Neoplastic cells had oval, vesicular nuclei with 12 prominent nucleoli. There was moderate

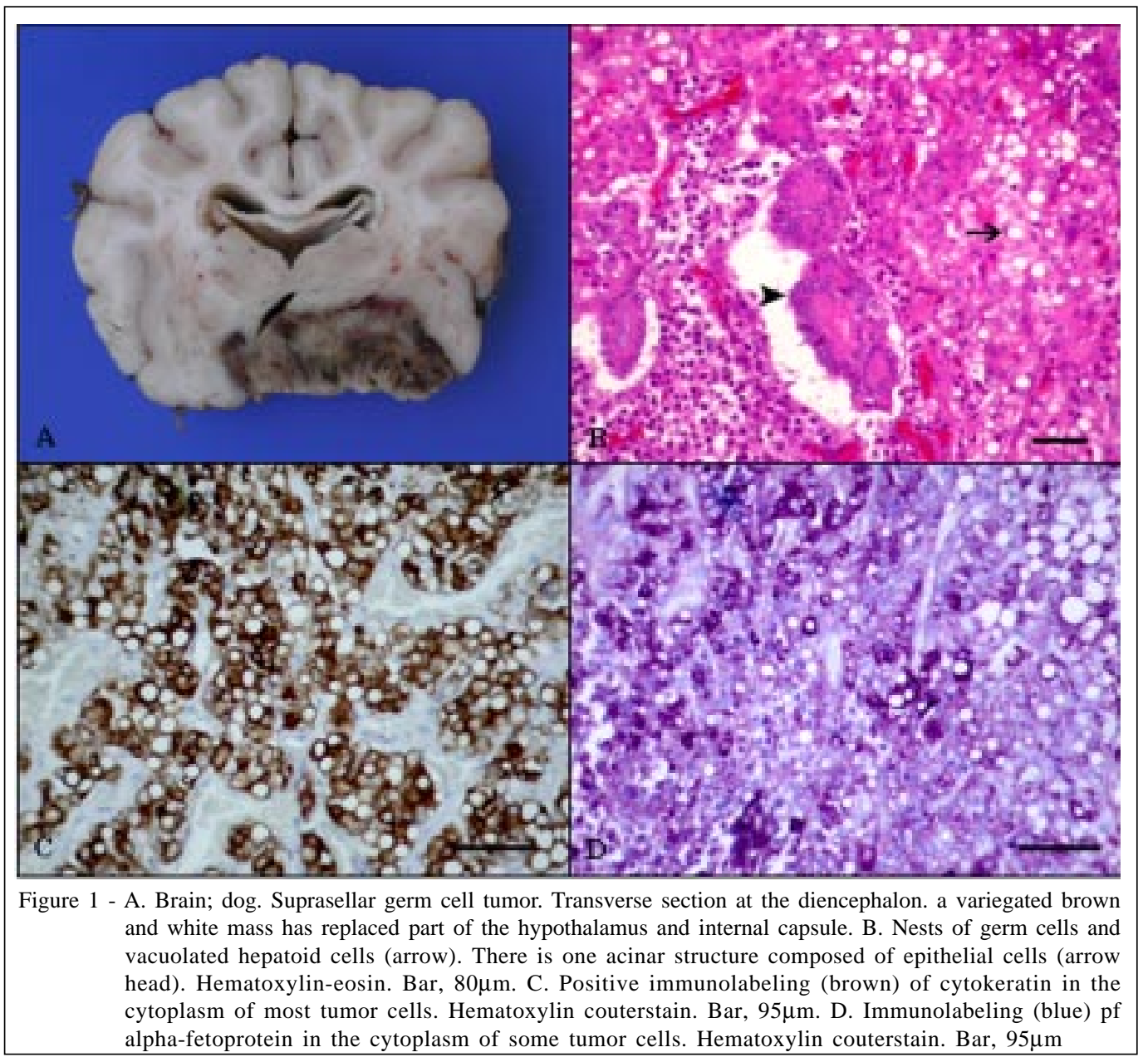

Ciência Rural, v.38, n.3, mai-jun, 2008. 
anisokaryosis and the mitotic rate averages 1-2 per 10 high power fields. Within the neoplasm there were variably sized areas of hemorrhage and necrosis and there were fibrin thrombi. Neoplastic cells were immunopositive for cytokeratin (Kermix) (Figura 1C) and alpha-fetoprotein (Figura 1D).

There is considerable debate on the origin of suprasellar pleomorphic neoplasms. Suprasellar germ cell tumors presumably develop from ectopic germinal epithelium, whereas in humans, craniopharyngiomas presumably derive from remnants of Rathke's pouch (HAWKINS et al., 1985; KOESTNER \& HIGGINS, 2002). Recently, it has been proposed that suprasellar pleomorphic neoplasms be classified as suprasellar germ cell tumors rather than craniopharyngiomas based on the following criteria: (1) mildline suprasellar location; (2) varying populations of neoplastic cells composed of a mixture of germinatous (seminoma/ dysgerminoma-like) areas, hepatoid cells, and areas with intestinal or respiratory epithelial differentiation; and (3) positive staining for alpha-fetoprotein (KOESTNER, 1999; NYSKA et al., 1993). Therefore, in this case, the characteristic histomorphologic features, location, and results of the immunohistochemical stains support the diagnosis of a suprasellar germ cell tumor.

\section{REFERENCES}

FERREIRA, A.J.A. et al. Mixed germ cell tumour of the spinal cord in a young dog. Journal of Small Animal Practice, v44, p.81-84, 2003.

HARE, W.R. Primary suprasellar germ cell tumor in a dog. Journal of the American Veterinary Medical Association, v.203, p.1432-1433, 1993.

HAWKINS, K.L. et al. Craniopharyngioma in a dog. Journal of Comparative Pathology, v.95, p.469-474, 1985.

KOESTNER, A. Histological classification of tumors of the nervous system of domestic animals. Washington DC.: WHO, 1999. 71p.

KOESTNER, A.; HIGGINS R.J. Tumors of the nervous system. In: MEUTEN D.J. Tumors of domestic animals. 4.ed. Iowa: Iowa State University, 2002. chap.14, p.697-738.

NYSKA, A. et al. Suprasellar differentiated germ cell tumor in a male dog. Journal of Veterinary Diagnostic Investigation, v.5, p.462-467, 1993.

PATTERSON-KANE, J.C. et al. Mixed germ cell tumor in the eye of a dog. Veterinary Pathology, v.38, p.712-714, 2001.

SUMMERS, B.A. et al. Tumors of the central nervous system. In: ___ Veterinary neuropathology. St Louis: Mosby, 1995. Cap.6, p.351-401. 527p.

VALLENTINE, B.A. et al. Suprasellar germ cell tumors in the dog: a report of five cases and review of the literature. Acta Neuropathologica,v.76, p.94-100, 1988. 